\title{
Measuring English Language Education Department Students' Speaking Fluency Level
}

\author{
Sendi Winaryo ${ }^{1}$, Rosalin Ismayoeng Gusdian ${ }^{2}$ \\ ${ }^{1,2}$ Universitas Muhammadiyah Malang \\ e-mail: ${ }^{1}$ sendhiwinaryo@gmail.com, ${ }^{2}$ rosalingusdian@umm.ac.id

\begin{tabular}{ccc}
\hline Diterima & Direvisi & Disetujui \\
$22-01-2021$ & $23-02-2021$ & $02-03-2021$ \\
\hline
\end{tabular}

\begin{abstract}
This research aimed at investigating English Language Education department students' speaking fluency level. The research subjects were twelve third-semester students of English Language Education Department at the University of Muhammadiyah Malang. Quantitative method was used in this research. The data were collected in the form of audio transcription. Three fluency standards were used, namely speech rate, pause rate, and disfluent syllable. The result showed that all of the students obtained the disfluent syllable, with a score below 30 disfluencies per minute. The majority of students obtained a low level of speaking fluency in terms of speech rate and pause rate. The average of students' speech rate was below 162 syllables per minute and the majority of students' pause rate was above 1 second. In conclusion, two students achieved level 3 (good) of speaking fluency and ten other students achieved level 2 (intermediate).
\end{abstract}

Key Word: English language education students, fluency level, speaking

\begin{abstract}
Abstrak - Penelitian ini bertujuan untuk mengetahui tingkat kefasihan berbicara mahasiswa jurusan Pendidikan Bahasa Inggris. Subjek penelitian adalah dua belas mahasiswa semester tiga Jurusan Pendidikan Bahasa Inggris di Universitas Muhammadiyah Malang. Metode kuantitatif digunakan dalam penelitian ini. Data dikumpulkan dalam bentuk transkripsi audio. Tiga standar kefasihan yang digunakan, yaitu kecepatan bicara, kecepatan jeda, dan suku kata disfluen. Hasil penelitian menunjukkan bahwa semua siswa memperoleh suku kata tidak lancar, dengan nilai di bawah 30 disfluen per menit. Mayoritas siswa memperoleh tingkat kefasihan berbicara yang rendah dalam hal kecepatan bicara dan kecepatan jeda. Rata-rata kecepatan bicara siswa di bawah 162 suku kata per menit dan mayoritas kecepatan jeda siswa di atas 1 detik. Kesimpulannya, dua siswa mencapai tingkat 3 (baik) dari kefasihan berbicara dan sepuluh siswa lainnya mencapai tingkat 2 (sedang).
\end{abstract}

Kata Kunci: berbicara, mahasiswa pendidikan bahasa Inggris, tingkat kelancaran

\section{INTRODUCTION}

Learning speaking is not appropriate if the learners try to stay away from the fluency (Harmer, 2007). Fluency is one of the factors that support the success of transferring information to others as it is the capacity of the speaker to create speech at the same tempo without having any problems such as reluctance, quiet pauses, filled pauses, repetition or false start (Stockdale, 2009). Fluency also involves the flow, smoothness, the rhythm of speech, the length of utterances, the connection of ideas, the absence of long pauses (Luoma, 2004). Fluency occurs when someone speaks a foreign language as a native speaker with the fewest pauses of silence, but not as accurately as the native speaker can (Brougthon et al, 2003; Stockdale, 2009).

Therefore, fluency is the crucial thing in learning speaking especially for English learners. In this case, students need to develop their speaking skill in class. Students need to develop their ability to speak by implementing the language confidently and fluently, with little hesitation and sufficient vocabulary (Nation and Newton, 2009). Being able to speak up fluently has become a vision of most EFL learners. When EFL learners could speak English as easily as at native speaker does, people will see that they are successful individuals in learning English. It will lead them in having more effective and efficient communication in which it will be very helpful for them on pursuing their career.

In English Language Education Department of University of Muhammadiyah Malang, speaking course is compulsory. Students in English Language Education Department must speak English until there is no hesitation, and pauses of silence for them in speaking English. However, from the initial observation the researcher found that some students still speak in English with some pauses and repeating words.

Several previous studies were conducted to measure students' fluency by using their audio transcription (Redeka, 2017; Hidayat 2018; Haidara 2016) . In his investigation, Redeka (2017) showed 
that students could not speak fluently because most of them had insufficient vocabulary; moreover the students were often confused when they were speaking. This issue caused a problem to students' fluency in delivering their ideas. In addition, Hidayat (2018) found that many respondents who were fourth semester students in at the advanced speaking class achieved scale 2 (poor) of their fluency level. That was because they were feeling nervous, and having limited vocabulary. Besides, the research by Haidara (2016) found that students were weak in English as they were lacking of English foundation backgrounds. Besides, they felt less confident in speaking English as they are afraid of making mistakes and feeling shy. The previous studies mainly described the students' problems in fluency and determined their fluency level by listening to the students' speaking performance and filling up the fluency-rating rubrics. However, to the best of the researchers' knowledge, there has not been any previous research determining the students' speaking fluency level by counting the syllables spoken in a certain point of time. Thus, based on the above explanation, the current study aims at analyzing the third semester students' speaking fluency level by using the utterance-based test, which consists of speech rate, pause rate, and disfluent syllable.

Speech rate itself refers to the number of syllables that a person could produce per minute (Tennessee Department of Education Fluency Resource Packet, 2009). The pause rate is applied for the pause over 0.2 seconds, and the number of disfluencies is counted based from Bloom \& Cooperman (1999). To determine the level of fluency using the mean length of pauses, the researcher uses the theory from Campione and Veronis (2002) and Heldner and Edlund (2010). They said that if the mean length of pauses is 0.2 seconds or below, it is considered as a brief pause and the speakers have high fluency. If the mean length of pauses is between $0.2-1$ seconds, it is a medium pause and the speakers have a medium or moderate fluency, while if the pauses is over 1 seconds, the speakers have a low fluency. For calculating disfluent syllable, the parameter of a speaker is considered as fluent when they only have 8 or less number of disfluencies per 100 syllables, on the contrary if they have $32-60$ number of disfluencies, it is a moderate fluency, and above 60 , it is less or low fluency.

\section{METHODS}

The quantitative design were used in this study to find out the students' level of speaking fluency. The study employed the convenient sampling. Twelve students joining a Speaking for Informal class were involved as the respondents. In collecting the data, each student joined an oral test, in which they were given two minutes to deliver a speech based on a recent video they have watched. The instrument internally validated by an expert, who is a lecturer convening Speaking class. After that, all data were transcribed. In transcribing the data, certain codes indicating pauses, unfinished words, corrections, repetitions, and prolongations are used. The codes are ( ): for silent pauses or hesitations, $\langle\mathrm{FP}\rangle$ : for filler pauses, (UF): for unfinished word, (c): for corrections, (r): for repetitions, (p):for prolongations. There were three standards that used to determine the fluency level of the students, they were: the speech rate, pause rate, and disfluent syllables. Then, the transcribed data were analyzed to find out the fluency level of the students. The components used to measure the fluency level included Speech Rate (Tennessee Department of Education Fluency Resource Packet, 2009), Pause Rate (Campione and Véronis, 2002; Heldner and Edlund, 2010) and Disfluent Syllables(Kormos and Dénes, 2004; Ano, 2005; Karimy and Piskhar, 2017).

\section{FINDINGS AND DISCUSSION}

It has been found that the twelve students produced speech rate, pause rate, and disfluent syllables during their oral speech. Each of the findings is presented as follows.

\section{Speech Rate}

Speech Rate (SR) is found by counting the total syllables. The number of syllables is then divided by the total time required (in this case is 2 minutes). To produce the speech sample in seconds, the results are multiplied by 60 to find syllables produced per minute. The speech rate of all students varies as shown on the table below. The table includes Number of Spoken Syllables (NSS) and Syllables per Minute (SPM).

Table 2: Speech Rate

\begin{tabular}{|c|c|c|}
\hline Students & NSS & SPM \\
\hline $\mathrm{A}$ & 143 & 71.5 \\
\hline B & 372 & 186.0 \\
\hline $\mathrm{C}$ & 167 & 83.5 \\
\hline $\mathrm{D}$ & 129 & 64.5 \\
\hline $\mathrm{E}$ & 176 & 88.0 \\
\hline $\mathrm{F}$ & 338 & 169.0 \\
\hline $\mathrm{G}$ & 145 & 72.5 \\
\hline $\mathrm{H}$ & 129 & 64.5 \\
\hline $\mathrm{I}$ & 56 & 28.0 \\
\hline $\mathrm{J}$ & 192 & 96.0 \\
\hline$\overline{\mathrm{K}}$ & 89 & 44.5 \\
\hline $\mathrm{L}$ & 85 & 42.5 \\
\hline
\end{tabular}

To give the standard of Speech Rate, (Tennessee Department of Education Fluency Resource Packet, 2009) has stated that the number of 
syllables that a fluent person normally produces is between 162 and 230 syllables per minute. From the table above, the total syllables spoken in two minutes were different with each other. The highest score was obtained by student B, it was 372 total syllables spoken in two minutes, so his speech rate was the result of dividing 372 and the sample time expressed in seconds and multiplied by 60 . It was 186.0 syllables per minute (spm). Student F had 338 syllables spoken and the speech rate was 169 . Student J obtained the total syllables spoken of 192 with the speech rate of 96 , student E with 176 total syllables spoken and 88.0 syllables per minute (spm); C had 167 total syllables spoken and 83.5 syllables per minute of the speech rate; $G$ obtained 145 total syllables spoken, with the speech rate of 72.5, student A had 143 syllables spoken with 71.5 spm, student $\mathrm{H}$ and student $\mathrm{D}$ obtained the same score, it was 129 syllables per minutes and the speech rate was 64.5 syllables per minutes, student $\mathrm{K}$ had 89 syllables spoken with the speech rate of 44.5 syllables per minutes, student $\mathrm{L}$ had 85 syllables spoken with $42.5 \mathrm{spm}$, and lastly student I had the lowest score, it was 56 syllables spoken with 28 total syllables per minutes.

Meanwhile, according to the table, the average of the speech rate of every student is below 162 SPM as the standards of fluent people can produce. Thus, it can be assumed that the students obtain a low level of fluency. Although there were two students get a considerably high score over 162, there are still many fillers and hesitations or pauses found. It somehow influences the total number of syllables they have spoken.

\section{Pause Rate}

Pause Rate (PR) is obtained by dividing the total length of pauses above 0.2 seconds and total number of pauses above 0.2 seconds. According to Campione and Véronis (2002) and (Heldner and Edlund 2010), if the average duration of pauses is 0,2 seconds or fewer, the speaking time is called a short break and the speakers are considered fluent. Meanwhile, if the medium pause duration is from 0.2 to 1 second, the speakers have a moderate fluency. If the delays are longer than 1 second, the speakers have a low level of fluency.

Table 3 indicates the pause rate of each students. It includes Total Pause Length above 0.2 Seconds (TPL > 0.2), Total Pause Number above 0.2 Seconds (TPN > 0.2), Mean Length of Pauses (MLP).

Table 3: Pause Rate

\begin{tabular}{|c|c|c|c|}
\hline Students & TPL $>$ 0.2 & TPN $>\mathbf{0 . 2}$ & MLP \\
\hline A & 11.69 & 3 & 3.89 \\
\hline B & 13.8 & 15 & 0.92 \\
\hline C & 28.63 & 17 & 1.68 \\
\hline
\end{tabular}

\begin{tabular}{|c|c|c|c|}
\hline $\mathrm{D}$ & 4.55 & 5 & 0.91 \\
\hline $\mathrm{E}$ & 12.54 & 8 & 1.56 \\
\hline $\mathrm{F}$ & 8.56 & 12 & 0.71 \\
\hline $\mathrm{G}$ & 15.26 & 13 & 1.17 \\
\hline $\mathrm{H}$ & 4.95 & 4 & 1.23 \\
\hline $\mathrm{I}$ & 7.29 & 8 & 0.91 \\
\hline $\mathrm{J}$ & 23.53 & 14 & 1.68 \\
\hline $\mathrm{K}$ & 17.9 & 10 & 1.79 \\
\hline $\mathrm{L}$ & 17.23 & 6 & 2.87 \\
\hline
\end{tabular}

Based on the table above, student A had the longest score of pauses, it was 11.69 total length of pauses, and he had 3 times pauses which was above 0.2 seconds. Because the mean length of pauses was calculated by dividing the total length of pauses above 0.2 seconds and divided by the total number of pauses above 0.2 seconds, so student A had 3.89 seconds as pause rate. Student L obtained 17.23 as the total length of pauses with 6 times of pauses, so student L had 2.87 seconds of pause rate. Student K had 17.9 seconds the total length of pauses, 10 times of pauses, and the pause rate was $1.79 \mathrm{~s}$. The score of student $\mathrm{D}$ was the same as student $\mathrm{J}$, they were had $1.68 \mathrm{~s}$ of the pause rate, student $\mathrm{E}$ had $12.54 \mathrm{~s}$, with 8 times of pauses, and the pause rate was 1.56.

Student $\mathrm{H}$ had 4.95 and did 4 times pauses and obtained $1.23 \mathrm{~s}$ of pause rate, student $\mathrm{G}$ had 15.26 with 13 times pauses and 1.17 of pause rate, student $\mathrm{B}$ had 13.8 total length of pauses and 15 times pauses, so student B obtained $0.92 \mathrm{~s}$ of pause rate. The total score of student D was the same as the total score of student I, it was $0.91 \mathrm{~s}$ of pause rate. The shortest pauses were obtained by student $\mathrm{F}$, it was $8.56 \mathrm{~s}$ of the pause rate, 12 times of the total number of pauses, and the pause rate was $0.71 \mathrm{~s}$. From the table above, most of the students obtained the length of pauses over 1 seconds. Thus, they were considered to have a low fluency.

In table 3 , it is found that most students obtain the length of pauses over one second. Thus, they are considered to have a low fluency.

\section{Disfluent Syllables}

According to Yarus (1998), the speakers are considered fluent if they only have eight or fewer number disfluencies present per 100 syllables. If they achieve $32-60$ disfluencies, they are considered moderately fluent. If they have more than 60 disfluencies, they have a low fluency. The students' disfluent syllables are presented in Table 4. The data in the table include The Number of Disfluency (ND) and Total Number of disfluency (TND).

Table 4: Disfluent Syllables

\begin{tabular}{|c|c|c|}
\hline Students & ND & TND \\
\hline A & 28 & 14 \\
\hline
\end{tabular}




\begin{tabular}{|c|c|c|}
\hline B & 29 & 14.5 \\
\hline C & 17 & 8.5 \\
\hline D & 28 & 14 \\
\hline E & 28 & 14 \\
\hline F & 31 & 15.5 \\
\hline G & 18 & 9 \\
\hline I & 3 & 1.5 \\
\hline K & 20 & 10 \\
\hline L & 6 & 3 \\
\hline
\end{tabular}

From the table above, student $\mathrm{F}$ obtained the highest number of disfluencies, the total number of disfluencies in a sample time was 31 and the number of disfluencies itself was 15.5. Student B had 29 of the total number on a sample time and 14.5 as the number of disfluencies, total number of disfluencies in a sample time obtained by student A, student $\mathrm{D}$, student $\mathrm{E}$ were the same, it was 28 and the number of disfluencies itself was 14 , student $\mathrm{J}$ obtained 20 of the total disfluencies and 10 of the total of disfluencies per minutes, student $\mathrm{G}$ obtained 18 of the total disfluencies and 9 of the total of disfluencies per minutes, student $\mathrm{C}$ obtained 17 disfluencies and 8.5 as the number of disfluencies per minutes, student $\mathrm{H}$ obtained 11 of the total disfluencies and 5.5 of the total of disfluencies per minutes, student $\mathrm{K}$ obtained 6 of the total disfluencies and 3 of the total of disfluencies per minutes, student I obtained 3 of the total disfluencies and 1.5 of the total of disfluent syllable, and the last was student $\mathrm{L}$ who obtained the lowest number of disfluencies, he obtained 2 of the total number of disfluencies with 1 of the total number of disfluency per minutes. In the findings, the students' number of disfluencies is fewer than 32 disfluencies per minute. Thus, according to the range of the number of disfluencies, the students could be considered as fluent.

\section{Fluency Level}

To get the fluency level, the mean scores of Speech Rate, Pause Rate, and Disfluent syllablesmatched with the Fluency Scale Ordinate by Jong and Hulstijn (2009) and the result as shown in figure 1.

Figure 1: Fluency Level

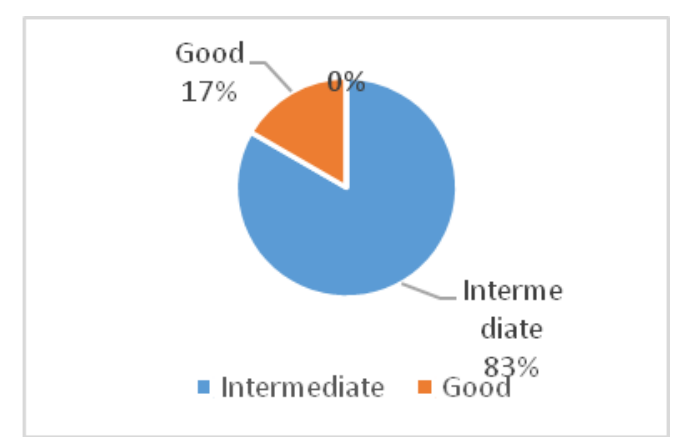

From the data above, the answers to the research questions were identified clearly. The first question was to find out how was the students' speaking fluency level while the second question was what dominant level of students speaking fluency. In addition, the figure showed that very few students have a good level of fluency and majority of them have a low level of fluency. Thus, it can be inferred that the students speaking fluency level is level 2 which means they achieved intermediate level of speaking fluency.

In this research, the assessment standards for fluency were three; the speech rate, pause rate, and disfluent syllable. The standards are based on several experts. For example, Kormo and Dénes (2004) stated that assessing fluency is conducted by calculating the articulation rate, speech rate, number of pauses per minute, pace, mean length of pauses, number of disfluencies. Ano (2005) claimed that to assess the fluency level, number of words per minute, number of silent thinking, number of repetition of words, phrases, and sounds had to be calculated. Whereas, Karimy and Pishkar (2017) explained that the number of pauses and the length of run or the number of syllables uttered between pauses were counted to know the fluency level. Three of the experts above had some similarities in assessing the fluency level of a speaker. The speech rate from Kormos and Dénes (2004) was already included the number of syllables per minute proposed by Ano (2005). The pause rate from Kormos and Dénes (2004) was the same as Karimy and Pishkar (2017). That was why, the researcher took only three which was already covered from all the three experts.

Meanwhile, based on the explanation from the research findings, the students obtained intermediate fluency level of speaking. Although the pause rate indicated the low fluency, but the other two factors or standards, the speech rate and the number of disfluent syllables stated that they have a good level in speaking.

Related to the research result, the students' score in pause rate indicated that they have a low level of fluency, the researcher came to believe that the students have some difficulties regarding their fluency in pause rate. Redeka (2017) showed that the students' difficulties in speaking were the students have limited vocabulary, the students feel confused when they want to pronounce the word, and they always feel insecure when they are speaking. Those findings also in line with Hidayat (2018) stating that, the students' problems concerning to their fluency were namely 1) the students are lack of vocabulary, 2) they often feel anxiety and nervous, and 3) they are lack of confidence when they are speaking. In this case, those difficulties can influence their fluency in pause rate in which, the students will take 
a long break in finding an appropriate word to say, that is why it can lead them to have long pauses during their speech. Moreover, Haidara (2016) found that the psychological factor such as; fear of making mistakes, feeling hesitated, feeling shy, and dearth of confidence could affect negatively to the students' speaking performance. In this case, they might have to do a lot of filler pauses and words or syllables repetitions during their speech in which, it can increase the number of typical disfluencies and lead them to have low fluency in disfluent syllable.

\section{CONCLUSION}

In conclusion, the result was the students possessed an intermediate level of speaking fluency. Based on the research finding, it showed that even if some students had a higher score of speech rate, but it does not mean that they are free from mistakes. There were still many disfluencies they made during their speech such as filler pauses, repetition, prolongation, and long silent pauses. As a matter of fact, it was found that the majority of the student still have long silent pauses, and the score of the speech rate was below the standard. Briefly, the speech rate and pause rates were the main holders and problems so that they could not achieve a higher level of speaking fluency. Therefore, it is believed that the students have to practice more to improve their speaking skills. proposed by some experts that have been explained in this research.

For the students, it is highly suggested that the students practice their speaking more, this effort can further help the students to improve their speaking and to achieve better speaking fluency. It is also suggested to the students not only produce a good utterance or continuous speaking, but also, they need to have self-correction to avoid long silent pauses and filler pauses, it might be hard in doing self-correction but, more practice can be so much helpful.

For the next researcher, it is highly suggested that the next researcher finds different speaking fluency scale, and include more standards from the experts so there will be more comprehensive study of fluency.

\section{REFERENCES}

Ano, K. (2005). Fluency and accuracy in the spoken English of Japanese high school learners. Journal of Japan - Korea Association of Applied Linguistic, 9-16.

Ary, D., Jacobs, L. C., Sorensen, C., \& Razavieh, A. (2010). Introduction to research in education. Belmont: Wadsworth.
Brougthon, G. et al. (2003). Teaching English as a Foreign Language. New York: Routledge.

Brown, H. D. (2004). Language assessment: principles and classroom practices. New York: Pearson Education.

Campione, E., \& Véronis, J. (2002). A Large-Scale Multilingual Study of Silent Pause Duration. ISCA Archive, 1-4.

Creswell, J. W. (2012). Fourth Edition: Educational Research; Planning, Conducting and Evaluating Quantitative and Qualitative Research. Boston: Pearson.

Haidara, Y. (2016). Psychological factor affecting English speaking performance for the English learners in Indonesia. Universal Journal of Educational Research. 4.,(7): 1501-1505. Mali: University of Bamako, Mali.

Harmer, J. (2007). The Practice of English Language Teaching. Harlow: Pearson Longman.

Heldner, M., Edlund, J. (2010). Pauses , gaps and overlaps in conversations. Journal of Phonetics, 38(4):555-568.

Hidayat, B. (2018). An Analysis of Students' Speaking Fluency of English Language Education Department at Fourth Semester of University of Muhammadiyah Malang. Unpublished Thesis. University of Muhammadiyah Malang.

Jong, N. De., Hulstijn, J. (2009). Relating ratings of fluency to temporal and lexical aspects of speech. (June).

Karimy, S., Piskhar, K. (2017). The Relationship Among Students' Speaking Accuracy and Fluency and Teachers' Oral Skill Class Presentation. Journal of Applied Linguistic and Language Research, 4,(2), $47-56$.

Kormos, J., \& Dénes, M. (2004). Dénes, M. (2004). Exploring measures and perceptions of fluency in the speech of second language learners. Budapest: Eötvös Loránd University, Budapest.

Lennon, P. (1990). 'Investigating fluency in EFL: a quantitative approach'. Language Learning, 40: $387-417$

Luoma, S. (2004). Assessing Speaking. Cambridge: Cambridge University Press.

Nation, I. S. P., \& Newton, J. (2009). Teaching ESL/EFL listening and speaking ( $\mathrm{T}$. and 
Francis, Ed.). Routledge.

Redeka, S. C. (2017). An Analysis of Students' Speaking Fluency of International Relations Students at Sixth Semester of University Muhammadiyah Malang. Unpublished Thesis. University of Muhammadiyah Malang.

Stockdale, D. A. (2009). Comparing Perception of Oral Fluency to Objective Measures in the EFL Classroom (Unpublished Thesis). Birmingham: University of Birmingham..

Tennessee Department of Education Fluency Resource Packet. (2009). Assessment of Speech: Determination of Speech Impairment : Fluency.

Yarus, J. S. (1998). Real-Time Analysis of Speech Fluency: Procedures and Reliability Training. 